\title{
Evaluation of wound healing properties of bioactive aqueous fraction from Moringa oleifera Lam on experimentally induced diabetic animal model
}

This article was published in the following Dove Press journal:

Drug Design, Development and Therapy

24 May 2016

Number of times this article has been viewed

\author{
Abubakar Amali \\ Muhammad' \\ Palanisamy Arulselvan' \\ Pike See Cheah ${ }^{2}$ \\ Farida $\mathrm{Abas}^{3}$ \\ Sharida Fakurazi ${ }^{1,2}$ \\ 'Laboratory of Vaccine and \\ Immunotherapeutics, Institute \\ of Bioscience, ${ }^{2}$ Unit of Anatomy, \\ Department of Human Anatomy, \\ Faculty of Medicine and Health \\ Sciences, ${ }^{3}$ Department of Food \\ Science, Faculty of Food Science and \\ Technology, Universiti Putra Malaysia, \\ Serdang, Malaysia
}

\begin{abstract}
Diabetic foot ulcer is a serious complication of diabetes, which affects a significant percentage $(15 \%)$ of diabetics and up to $15 \%-24 \%$ of those affected may require amputation. Therefore, the economic burden of diabetic foot ulcers is enormous and is associated with high cost of treatment and prolongs hospitalization. The present study was conducted to evaluate antibacterial and in vivo wound healing activities of an aqueous fraction of Moringa oleifera on a diabetic condition. Antibacterial activity testing was carried out using agar well and tube dilution techniques. The in vivo study was conducted using six groups of animals that comprise of one normal and diabetic control group each, three treatment groups of $0.5 \%, 1 \%$, and $2 \% \mathrm{w} / \mathrm{w}$ aqueous fraction, and a positive control group ( $1 \% \mathrm{w} / \mathrm{w}$ silver sulfadiazine). Rats were induced with diabetes using a combination of streptozotocin 65 and $150 \mathrm{mg} / \mathrm{kg}$ nicotinamide daily for 2 days, and excision wounds were created and treated with various doses $(0.5 \%, 1 \%$, and $2 \% \mathrm{w} / \mathrm{w}$ aqueous fraction) daily for 21 days. Biophysical, histological, and biochemical parameters were investigated. The results of the study revealed that aqueous fraction possessed antibacterial activity through inhibition of growth of Staphylococcus aureus, Pseudomonas aeruginosa, and Escherichia coli organisms. The topical application of aqueous fraction revealed enhancement of wound healing under sustained hyperglycemic condition for the duration of the experiment. This enhancement was achieved through decreased wound size, improved wound contraction, and tissue regeneration, as well as downregulation of inflammatory mediators, such as tumor necrosis factor- $\alpha$, interleukin- $1 \beta$, interleukin- 6 , inducible nitric oxide synthase, and cyclooxygenase-2, and upregulation of an angiogenic marker vascular endothelial growth factor in wound tissue treated with various doses of aqueous fraction of $M$. oleifera. The findings suggest that aqueous fraction of M. oleifera containing Vicenin-2 active compound may accelerate wound healing in hyperglycemic condition.
\end{abstract}

Keywords: aqueous fraction, Vicenin-2, wound healing, inflammatory mediators

\section{Introduction}

As the world is facing an epidemic of type 2 diabetes, diabetic foot ulcers have become a major public health problem because of its socioeconomic burden on the patient, patient's family, and health care system of the country. ${ }^{1,2}$ Previous studies have suggested that the lifetime risk of developing a diabetic foot ulcer among diabetics is between $15 \%$ and $25 \%{ }^{3,4}$ It has also been reported that between $20 \%$ and $58 \%$ of patients with a diabetic foot ulcer develop another ulcer within a year after healing. ${ }^{5}$ Globally, billions of dollars are being spent in managing ulcer condition Boulton et al. ${ }^{6}$ For example, in the USA, the cost of managing diabetic foot ulceration and amputations stood at $\$ 10.9$ billion of the total health expenditure in the year 2001. In the UK, £3 billion was spent which represents $\sim 5 \%$ of total national health expenditure. ${ }^{7}$ Although data
Correspondence: Sharida Fakuraz Laboratory of Vaccines and Immunotherapeutics, Institute of Bioscience, Universiti Putra Malaysia, 43400 UPM Serdang, Selangor, Malaysia Tel +60389472331

Fax +60389422341

Email sharida.fakurazi@gmail.com
Drug Design, Development and Therapy 2016:10 1715-1730

1715

Dovepress

http://dx.doi.org/10.2147/DDDT.596968 (c) (1) (2) 12016 Muhammad et al. This work is published and licensed by Dove Medical Press Limited. The full terms of this license are available at https:///wwy.dovepress.com/terms.php cc. hereby accept the Terms. Non-commercial uses of the work are permitted without any further permisision from Dove Medical Press Limited, provided the work is properly attributed. For permision for commercial use of this work, please see paragraphs 4.2 and 5 of our Terms (https://www.dovepress.com/terms.php). 
about diabetic foot problems in Asia are sparse, amputations remain common in countries such as India and the People's Republic of China as in other developing countries. ${ }^{8}$ A retrospective study that was conducted in Malaysia showed that of the 203 amputated patients between years 2003 and 2005, $134(66 \%)$ were related to diabetes. ${ }^{9}$ The healing in acute wounds occur in an orderly manner through hemostasis, inflammation, epithelization, and maturation. When this process is altered, a nonhealing chronic wound will develop. ${ }^{10}$ Impaired healing is a common problem in diabetic wounds and often resistant to conventional wound management that ultimately threatens limb viability. ${ }^{11}$ Chronic wounds have been reported to be associated with microorganisms, ${ }^{12}$ and bacteria can colonize wounds within 48 hours after injury and may cause infection that affects the wound healing process by prolonging the inflammatory phase. ${ }^{13}$ The underlying pathogenesis of chronic wounds of diabetics may result in wounds affected by different bacteria, such as Pseudomonas aeruginosa strain PAO1, methicillin resistant Staphylococcus aureus, Escherichia coli (ATCC), Klebsiella pneumoniae, Proteus vulgaris, Streptococcus pneumoniae, and Streptococcus pygones. ${ }^{12,14}$ Clinically, the current treatment in topical wound management includes debridement, topical antibiotics, and a state-of-the-art topical dressing. State-of-the-art dressings are a multilayer system that can include a collagen cellulose substrate, neonatal foreskin fibroblasts, growth factor containing cream, and a silicone sheet covering for moist control. ${ }^{15}$ Despite these available treatments for diabetic foot ulcer, the rate of amputation still stands at $\sim 15 \%$. Wound healing time can be up to 20 weeks. ${ }^{15}$ This presents a major burden for the individual patient's health and well-being in addition to significant financial cost for health care systems. Plants contain various bioactive agents, such as alkaloids, flavonoids, tannins, and steroids, and these bioactive agents usually influence one or more phases of wound healing. ${ }^{16}$ Moringa oleifera from the family Moringaceae is a native plant of India, Pakistan, Bangladesh, and Afghanistan but is currently distributed in many countries of the tropics. ${ }^{17,18}$ The plant has been traditionally employed for treatment of skin diseases, anemia, cholera, and other ailments. ${ }^{19}$ It has been scientifically reported to possess antimicrobial, ${ }^{20}$ anti-inflammatory, ${ }^{21}$ antidiabetic, antioxidant, ${ }^{22}$ and anticancer properties. ${ }^{23}$ The hydroethanolic extract of $M$. oleifera leaves prophylactically and therapeutically protects against acetaminophen-induced hepatotoxicity in experimental rats through their antioxidant nature. ${ }^{24,25}$ In addition, it has been confirmed to possess significant hepatoprotective action. $^{24,26,27}$ We have previously reported in vitro wound healing activity of bioactive aqueous fraction of $M$. oleifera and also identified the putative bioactive compounds through secondary metabolite profiling. ${ }^{28}$ The present study was conducted to evaluate the antibacterial and in vivo wound healing activities of bioactive aqueous fraction obtained from the most active methanolic crude extract of $M$. oleifera leaves in diabetic-induced animals.

\section{Materials and methods Chemicals and reagents}

All extraction chemicals used were of analytical and HPLC grade (Merck Millipore, Germany), these include methanol, ethanol, hexane, dichloromethane, ethyl acetate, and butanol.

The chemicals used for diabetes induction include Streptozotocin (STZ) injection (Calibochem, San Diego, CA, USA) and nicotinamide (NAD) from Sigma-Aldrich Co., St Louis, MO, USA.

The protein assay kit used for protein extraction was Pierce $^{\mathrm{TM}} 660 \mathrm{~nm}$ Protein assay (Thomas Scientific, Swedesboro, NJ, USA), and phosphatase and protease inhibitors cocktail (Nacalai Tesque, Kyoto, Japan).

The chemicals used for western blotting, ELISA and immunohistochemistry were; 3,3-5,5-Tetramethyl benzidine substrate solution (Sigma-Aldrich Co., St Louis, MO, USA), super signal chemiluminescent substrate (Thermo Fisher Scientific, Waltham, MA, USA), tissue/cell lysis buffer, skim milk powder (Sigma, Aldrich, Germany), sample loading dye, sodium dodecyl sulfate solution (Bio-Rad Laboratories Inc., Hercules, CA, USA), PVDF membrane, coplin staining jars, 2-mercaptoethanol, mounting media, PAP pen, bovine serum albumin, and 30\% acrylamide/bis-acryl amide solution (Bio-Rad Laboratories Inc.).

Others included, ammonium persulfate, DAB substrate kit (BD Biosciences, San Jose, CA, USA). Isopropanol solution, Tween 20 solution, phosphate-buffered saline tablets (200 mg), diethiothreitol, protein ladders (10-170 KDA) cat No: $\neq$ SM0671, bromophenol blue (Bio-Rad Laboratories Inc.), glycerol, hydrogen peroxide ( $30 \%$ solution), $\mathrm{NaOH}$ pellet, Tris HCL, and TEMED solution.

The antibodies used were; NF-кB P65, TGF- $\beta 1$, MMP-9, vascular endothelial growth factor (VEGF) (C-1), $\beta$-actin, cyclooxygenase-2 (COX-2), inducible nitric oxide synthase (iNOS), mouse antirabbit IgG-HRP, and goat antimouse IgGHRP conjugated all from Santa Cruz Biotechnology Inc., Dallas, TX, USA. Interleukin (IL)-1 $\beta$, IL-6, tumor necrosis factor (TNF)- $\alpha$ (DuoSet, R\&D Systems, Minneapolis, MN, USA).

The staining reagent used for histological and immunohitochemical analysis was Hematoxylin-eosin reagent (Merck Millipore, Japan). 


\section{Preparation of plant extract and fraction}

Matured leaves of $M$. oleifera Lam were collected from the farm unit of Faculty of Agriculture, Universiti Putra Malaysia, during the rainy season and authenticated by a botanist. A voucher specimen (SK 1561/10) was deposited at the herbarium of Institute of Bioscience. The air dried and powdered leaves were extracted by a maceration process with $80 \%$ methanol and the same procedure was repeated three times to achieve complete extraction of the crude extract with the help of shaking the incubator set at $27^{\circ} \mathrm{C}$ for 3 hours each time. Extracts were then filtered and evaporated to dryness under reduced pressure with rotary evaporator. The dried crude extracts were stored in a refrigerator at $-20^{\circ} \mathrm{C}$ for further use. An amount of $10 \mathrm{~g}$ of the dried active crude methanolic extract was redissolved in $200 \mathrm{~mL}$ water:methanol (1:3 v/v) mixture. The mixture was then fractionated in $200 \mathrm{~mL}$ each of hexane, dichloromethane, ethyl acetate, and butanol using a separation funnel. The separation was carried out in order of increasing polarity; thus, five corresponding fractions were obtained. ${ }^{29}$ The mixture to be separated in solution was added through the top with the stopcock at the bottom closed. The funnel was then closed and shaken gently by inverting the funnel multiple times until the solutions were mixed vigorously. The funnel was then inverted and the tap carefully opened to release excess vapor pressure. The separating funnel was set aside to allow for complete separation of the phases. The top and the bottom taps were then opened and the lower phase was released; the stopcock was then closed, and the upper layer was poured out through the top into another container. This was done for each solvent until the mixture was completely separated. The fractions were subjected to bioguided assay fractionation to obtain the most active aqueous fraction as previously mentioned. The choice of aqueous fraction for this experiment was made because it has been found to be the most active fraction from the results of a bioguided assay fractionation of different solvent fractions of active methanolic crude extract of $M$. oleifera as previously reported in our study. ${ }^{28}$

\section{Antibacterial susceptibility test and determination of MIC}

Pathogenic bacteria consisting of $P$. aeruginosa strain PAO1, methicillin resistant $S$. aureus, and E. coli (ATCC) were obtained from the Microbiology Unit of the Faculty of Medicine and Health Sciences, Universiti Putra Malaysia. The sensitivity testing of aqueous fraction was done using the agar well diffusion method. ${ }^{30}$ Serial dilutions were made to give final concentrations of $10,20,40$, and $80 \mathrm{mg} / \mathrm{mL}$ of aqueous fraction which were added to agar whereby wells of $6 \mathrm{~mm}$ diameter and $5 \mathrm{~mm}$ depth were made on the solid agar using a sterile glass borer; the setup was incubated at $37^{\circ} \mathrm{C}$ for 24 hours after which the zones of inhibition were measured using a ruler and a pair of dividers, and then the results are reported in millimeters. Ciprofloxacin and chloramphenicol standard antibiotics were used as positive controls since they are broad spectrum antibiotics. Tests were performed in triplicate and average values were used for analysis. For determination of minimum inhibitory concentration (MIC), 24-hour bacterial culture was diluted in sterile normal saline with reference to the $0.5 \mathrm{McFarland}$ standards at $10^{6} \mathrm{CFU} / \mathrm{mL}$. Serial dilution of $3.125,6.25,12.5$, and $25(\mu \mathrm{g} / \mathrm{mL})$ aqueous fractions were made in test tubes. These were inoculated with $0.1 \mathrm{~mL}$ suspensions of the test organism and incubated at $37^{\circ} \mathrm{C}$. From each tube, $50 \mu \mathrm{L}$ was withdrawn and inoculated on agar plates and then incubated at $37^{\circ} \mathrm{C}$ for 24 hours. MIC values were determined as lowest concentrations of aqueous fraction that inhibited visible growth of the test microorganism after overnight incubation. ${ }^{31}$

\section{Preparation of aqueous fraction formulation}

A homogenous, semisolid ointment was formulated by incorporating the dried aqueous fraction of M. oleifera in a white soft paraffin base..$^{32,33}$ Briefly, soft paraffin ointment was melted using water bath. Each of the concentrations $(0.5 \%$, $1 \%$, and $2 \% \mathrm{w} / \mathrm{w}$ ) of aqueous fraction was dissolved in small quantity of distilled water and mixed gently using pestle and mortar. The mixture was then made up to a large volume by stirring and a soft ointment was obtained, which was used for topical application to the wounds of treated rats.

\section{Induction of diabetes in animals}

Healthy male Wistar rats weighing between 150 and $250 \mathrm{~g}$ were used for the study. They were housed in polycarbonated cages with sterilized rice husk bedding under controlled condition of 12 hours light/darkness cycle and a temperature of $25^{\circ} \mathrm{C} \pm 2{ }^{\circ} \mathrm{C}$. The animals were fed with commercial rat feed and tap water and allowed to acclimatize to environmental condition for 7 days prior to the commencement of the study. The experiment followed guidelines of Institutional Animal Care Use Committee of Faculty of Medicine and Health Sciences, University Putra Malaysia (Approval No: UPM/ FPSK/PADS/BR-UUH/00408).

Induction of hyperglycemic condition was done using a combination of STZ and NAD according to the dosage reported in previous studies. ${ }^{34-36}$ Briefly, rats were injected with intraperitoneally $150 \mathrm{mg} / \mathrm{kg}$ of NAD, followed by $65 \mathrm{mg} / \mathrm{kg}$ of STZ 15 minutes later. The induction procedure was repeated after 24 hours with the same dose of NAD and STZ. Blood was drawn from the tail after 72 hours to ensure successful 
induction of hyperglycemia, and glucose level was measured using a commercial glucometer (Accu-Check glucometer, Hoffman-La Roche Ltd., Basel, Switzerland). Rats with elevated blood glucose level ( $\geq 10 \mathrm{mmol} / \mathrm{L}$ ) were considered diabetic. ${ }^{35}$ Serum insulin level was determined using a commercial kit (Marcodia rat insulin enzyme linked immunosorbent assay (ELISA) cat No 10-1250-01). Physical parameters such as body weight, food, and fluid intake were also recorded at specific intervals during the experimental period.

Formalin-fixed paraffin embedded pancreatic tissues were cut into $4 \mu \mathrm{m}$ tissue sections. The sections were stained with hematoxylin-eosin and viewed under light microscope for the morphology of islet of Langerhans.

\section{Induction of wound in diabetic animals and treatment}

Prior to commencement of wound infliction, rats were anesthetized with intramuscularly xylazine $10 \mathrm{mg} / \mathrm{kg}$ and ketamine $90 \mathrm{mg} / \mathrm{kg}$. The area was marked with methylene blue and then shaved with an electric clipper at the dorsal back of the animal. ${ }^{37}$ Full thickness (extending up to adipose tissue) $6 \mathrm{~mm}$ diameter and $2 \mathrm{~mm}$ depth wounds were created using a sterile $6 \mathrm{~mm}$ biopsy punch. Wounds were left open and treated with prepared formulation. Various concentrations of formulated ointment of aqueous fractions of $M$. oleifera were applied topically to treatment groups of the animals daily for 21 days. The grouping of the animals is shown in Table 1.

Wounds were photographed with a digital camera on day $0,3,7,14$, and 21 to assess the progress of wound closure. Wound size (surface area of the wound) was measured by tracing the wound on day $3,7,14$, and 21 after wounding using a transparent paper and graph paper. ${ }^{16}$ Percentage wound contraction $(\% \mathrm{WC})$ was also determined using a formula:

$$
\begin{gathered}
\text { Initial wound size }- \\
\% \mathrm{WC}=\frac{\text { wound size at specific day }}{\text { Initial wound size }} \times 100 . .^{38}
\end{gathered}
$$

Table I Animal grouping

\begin{tabular}{llll}
\hline Group & $\begin{array}{l}\text { Number } \\
\text { of animals }\end{array}$ & Treatment & Dose \\
\hline i & 6 & $\begin{array}{l}\text { Vehicle only (white soft } \\
\text { paraffin ointment) } \\
\text { Vehicle only (white soft } \\
\text { paraffin ointment) }\end{array}$ & $\begin{array}{l}\text { Normal } \\
\text { control } \\
\text { Dii }\end{array}$ \\
Aquetic \\
iii
\end{tabular}

Granulation tissue formed on the wound was excised on day 14 which was the time it was observed to have manifested due to the slow healing nature of diabetic wound. It was weighed after collection and then dried in an oven at $60^{\circ} \mathrm{C}$, weighed again, and analyzed. ${ }^{39}$ The period of epithelialization was calculated as the number of days required for the dead tissue remnants (eschar) to fall without any residual raw wound. ${ }^{40}$

\section{Histological evaluation of skin wound tissues in control and diabetic-treated rats}

Formalin-fixed paraffin embedded wound tissue samples were cut into $4 \mu \mathrm{m}$ tissue sections. The sections were stained with hematoxylin-eosin and viewed under light microscope and graded with respect to epidermal regeneration, granulation tissue formation, and angiogenesis and migration of fibroblast cells; comparison was made between diabetic treated and diabetic control groups. ${ }^{41}$

\section{Determination of expression of inflammatory mediators}

\section{Protein quantification in wound tissue}

Total protein extraction reagent (Thermo Fisher Scientific, Product No 78510) was used to extract protein from wound tissue according to the manufacturer's instructions. Protein was quantified using a standard protein assay kit (Pierce ${ }^{\mathrm{TM}}$ $660 \mathrm{~nm}$ Protein Assay, Thermo Fisher Scientific). The optical density of the standard and unknown sample was measured at $660 \mathrm{~nm}$ using an ELISA plate reader (universal microplate reader) (Biotech Inc., Hawaii, USA). A standard curve was used to determine the protein concentration.

\section{Evaluation of cytokines levels via ELISA}

Wound tissue lysates were prepared from $5 \mathrm{~g}$ of fresh frozen tissue using a protein extraction reagent mixed with protease and phosphatase inhibitors. IL- $1 \beta$, IL- 6 , and TNF- $\alpha$ were measured and estimated by ELISA according to the manufacturer's instructions using the DuoSet ELISA Development (R\&D Systems). Results were evaluated statistically using one-way analysis of variance and $P<0.05$ was considered significant.

\section{Evaluation of cytokines by Western blotting}

Protein was extracted and quantified using a standard protein assay kit (Thermo Fisher Scientific, Pierce ${ }^{\text {TM }} 660 \mathrm{~nm}$ Protein Assay) according to the manufacturer's instruction. Equal amounts of protein $(30 \mu \mathrm{g})$ were resolved and separated in 10\% SDS-PAGE system (Bio-Rad Laboratories Inc.), transferred to PVDF membrane, and blocked for 1 hour in a blocking solution. Membranes were then probed with 
primary antibodies iNOS, COX-2, NF-kB, VEGF, and $\beta$-actin used as loading control (Santa Cruz Biotechnology Inc.) overnight at $4^{\circ} \mathrm{C}$. The following day, membranes were washed and incubated with secondary antibodies (horseradish peroxidase-conjugated antimouse or antirabbit at 1:2,000). Proteins were enhanced with ECL substrate and scanned using ChemiDoc ${ }^{\mathrm{TM}}$ MP System (Bio-Rad Laboratories Inc.). The results were expressed in standard units and intensity of bands analyzed using image $\mathrm{J}$ software (Biotech Inc).

\section{Determination of VEGF expression by immunohistochemistry}

Formalin-fixed paraffin embedded tissues were cut into $4 \mu \mathrm{m}$ sections. The slides were deparaffinized in xylene and dehydrated in graded alcohol series. Slides were rinsed in slow running water and a hydrophobic barrier was created with PAP pen. Slides were quenched in 3\% hydrogen peroxide to neutralize endogenous peroxidase activity, then washed in PBS-T, and blocked in $1 \%$ bovine serum albumin. Slides were incubated with primary antibody against VEGF (147) (Santa Cruz Biotechnology Inc.) at 1:400 dilution overnight at $4^{\circ} \mathrm{C}$. The slides were washed and incubated with biotinylated-conjugated goat antimouse IgG antibody (Santa Cruz Biotechnology Inc.) at 1:400 dilution for 1 hour at room temperature. Slides were washed and immediately treated with DAB chromogen substrate for 5 minutes, then counter stained in hematoxylin, and rinsed in deionized water. Slides were then rehydrated in alcohol and xylene, dried, and mounted on a DPX mounting medium. The slides were finally examined and photomicrographs were captured under microscope (Olympus image analyzer, Olympus Corporation, Tokyo, Japan).

\section{Statistical analysis}

Results were analyzed using SPSS version 20. Data were expressed as mean \pm standard deviation, and the results were selected from at least three independent experiments performed in triplicate. $P$-values of 0.05 were considered to be statistically significant.

\section{Results}

\section{Antibacterial activity and MIC of aqueous fraction}

Antibacterial susceptibility testing showed that the aqueous fraction of $M$. oleifera possessed antibacterial activity against $S$. aureus, $P$. aruginosa, and $E$. coli. The activity was expressed as a measure of zone of inhibition of bacteria growth by the aqueous fraction. The values range between 3.60 and $18.0 \mathrm{~mm}$, while standard ciprofloxacin and tetracycline antibiotics (positive controls) had a range of values between 13.0 and $17.0 \mathrm{~mm}$ (Table 2). The MIC values considered being the lowest concentration of aqueous fraction that inhibited growth of $S$. aureus and $P$. aeruginosa were found to be 3.125 and $6.25 \mu \mathrm{g} / \mathrm{mL}$ against $E$. coli. The MIC value for tetracycline standard antibiotic was $3.125 \mu \mathrm{g} / \mathrm{mL}$ against $E$. coli and $6.25 \mu \mathrm{g} / \mathrm{mL}$ against both $S$. aureus and P. aeruginosa. This is shown in Table 3.

\section{Effect of aqueous fraction on body weight, glucose, and insulin levels in rats}

Following treatment with aqueous fraction, the blood glucose level of diabetic-induced rats was found to rise from an initial normal range of $4.7-5.0 \mathrm{mmol} / \mathrm{L}$ before induction to as high as $27.0 \mathrm{mmol} / \mathrm{L} 72$ hours after induction and was sustained for 21 days (Figure 1). The persistent rise in blood glucose level was more significant in diabetic groups compared to normal control group $(P<0.05)$. However, serum insulin level in normal control group was high with a value range between 2.48 and $2.56 \mu \mathrm{g} / \mathrm{L}$ (Figure 2) and found to be more significant $(P<0.05)$ compared to diabetic-induced animals with a value range between 0.87 and $1.35 \mu \mathrm{g} / \mathrm{L}$ (Figure 2).

Table 2 Antibacterial activity of the aqueous fraction of Moringa oleifera against bacterial isolates

\begin{tabular}{lllll}
\hline Sample & $\begin{array}{l}\text { Concentration } \\
(\mathbf{m g} / \mathbf{m L})\end{array}$ & \multicolumn{2}{l}{$\begin{array}{l}\text { Organisms } \\
\text { (zones of inhibitions [mm]) }\end{array}$} \\
\cline { 2 - 5 } & & $\begin{array}{l}\text { Staphylococcus } \\
\text { aureus }\end{array}$ & $\begin{array}{l}\text { Pseudomonas } \\
\text { aeruginosa }\end{array}$ & $\begin{array}{l}\text { Escherichia } \\
\text { coli }\end{array}$ \\
\hline Aqueous fraction & 10 & $3.60 \pm 1.0$ & - & - \\
& 20 & $4.30 \pm .0$ & $3.60 \pm 1.0$ & - \\
& 40 & $6.60 \pm 1.5$ & $15.6 \pm 1.3$ & $3.60 \pm 1.0$ \\
Ciprofloxacin (+ve control) & 80 & $16.0 \pm 2.0$ & $12.0 \pm 1.8$ & $10.3 \pm 1.5$ \\
Tetracycline (+ve control) & 40 & $13.3 \pm 1.2$ & $13.0 \pm 1.2$ & $18.0 \pm 1.8$ \\
Distilled water (-ve control) & 40 & $17.0 \pm 1.4$ & 0 & - \\
\hline Notes Sus & 0 & 0 & 0 \\
\hline
\end{tabular}

Notes: Susceptibility testing of aqueous fraction and antibiotics (positive control) against bacterial isolates. Values are diameters of zones of inhibition. -, No inhibition. Data are presented as mean \pm standard deviation. Abbreviations: +ve, positive; - ve, negative. 
Table 3 Minimum inhibitory concentration (MIC) of aqueous fraction of Moringa oleifera

\begin{tabular}{|c|c|c|c|c|c|c|}
\hline \multirow[t]{2}{*}{ S no } & \multirow[t]{2}{*}{ Sample } & \multirow[t]{2}{*}{ Bacteria spp. } & \multicolumn{4}{|c|}{ Concentration in $\mu \mathrm{g} / \mathrm{mL}$} \\
\hline & & & 25 & 12.5 & 6.25 & 3.125 \\
\hline \multirow[t]{3}{*}{ I } & Aqueous fraction & E. coli & - & $-\alpha$ & + & + \\
\hline & of $M$. oleifera & S. aureus & - & - & $-\alpha$ & + \\
\hline & & $P$. aeruginosa & - & - & $-\alpha$ & + \\
\hline \multirow[t]{3}{*}{2} & Tetracycline & E. coli & - & - & $-\alpha$ & + \\
\hline & (+ve control) & S. aureus & - & - & $-\alpha$ & + \\
\hline & & P. aeruginosa & - & $-\alpha$ & + & + \\
\hline
\end{tabular}

Notes: -, no growth of bacteria; +, concentration showing growth of bacteria; $-\alpha$, MIC value.

Abbreviations: M. oleifera, Moringa oleifera; E. coli, Escherichia coli; S. aureus, Staphylococcus aureus; P. aeruginosa, Pseudomonas aeruginosa; S no, serial number; spp, species; +ve, positive; MIC, minimum inhibitory condition.

Histological observations of the pancreatic tissue in control and diabetic-induced rats

Histological examination of pancreas of normal control rats showed normal arrangement of the islets of Langerhans in the exocrine tissue with no visible lesion. The histology of pancreatic tissue in diabetic rats showed some degenerative changes with severe lesion in the exocrine tissue and a marked reduction in size of the islets of Langerhans (Figure 3).

\section{Effect of aqueous fraction on wound size and wound contraction in diabetic-treated rats}

Following wound induction and treatment with aqueous fraction, decreased wound size was observed in groups treated with $0.5 \%, 1 \%$, and $2 \%$ aqueous fraction from initial 431,430 , and $420 \mathrm{~mm}^{2}$ to 14,20 , and $4 \mathrm{~mm}^{2}$, respectively, on day 14 . On day 21 , the treated wounds were completely closed as against the untreated diabetic control group as shown in Figures 4 and 5. The decrease in wound size that indicated faster healing was significant compared to untreated diabetic control group $(P<0.05)$. The highest dose of $2 \%$ aqueous fraction treated group showed faster contraction rate from $59.7 \%$ on day 3 which progressed to $100 \%$ closure by day 21 . The contraction rate was significant compared to untreated diabetic control group $(P<0.05)$.

\section{Effect of aqueous fraction on epithelialization and granulation tissue in diabetic-treated rats}

Epithelization period occurs when the epithelial cells move across to cover the wound area. In this study, the epithelialization period recorded in aqueous fraction treated groups was $11 \pm 1$ days compared to a longer period recorded in untreated diabetic control of $15 \pm 1$ days as shown in Figure 6.

\section{Histological observation of wound tissues in control and diabetic-treated rats}

Presence of thick epidermal layer and connective tissue was observed in diabetic treated rats but these features

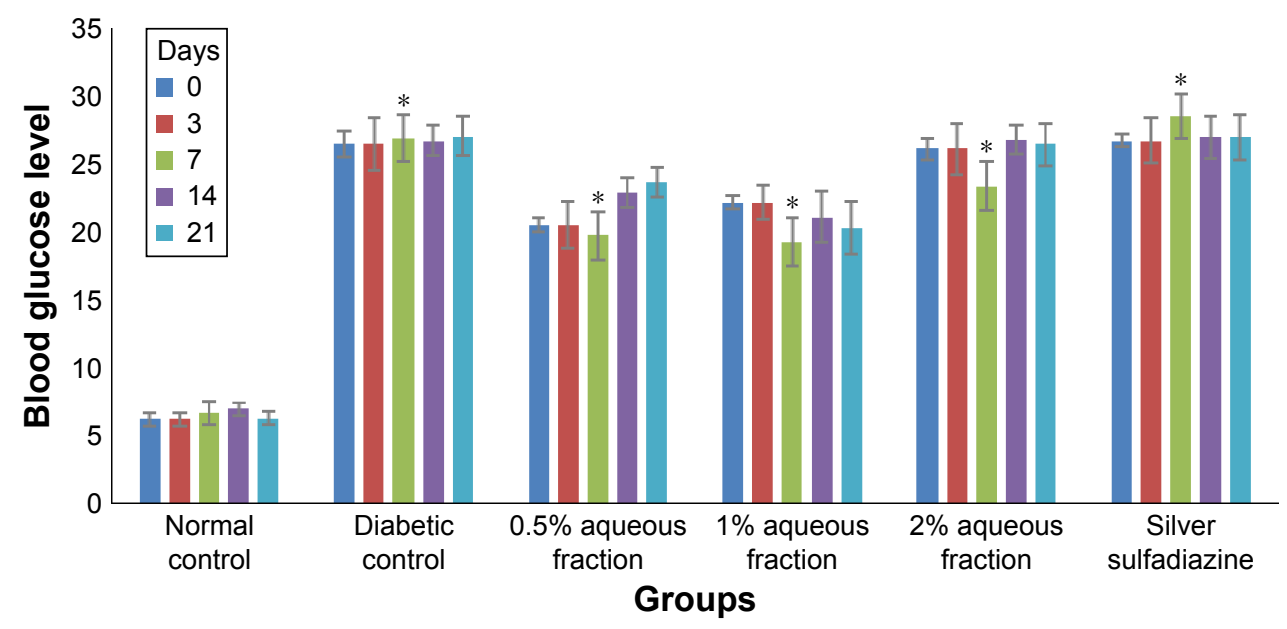

Figure I A graph comparing the concentration of blood glucose level of normal rats with streptozotocin-induced diabetic rats at day 0, 3, 7, I4, and 2I.

Notes: The increased blood glucose in diabetic rats is highly significant compared to normal rats $(* P<0.05$ diabetic vs control groups). Values are mean \pm standard deviation of three independent readings. 


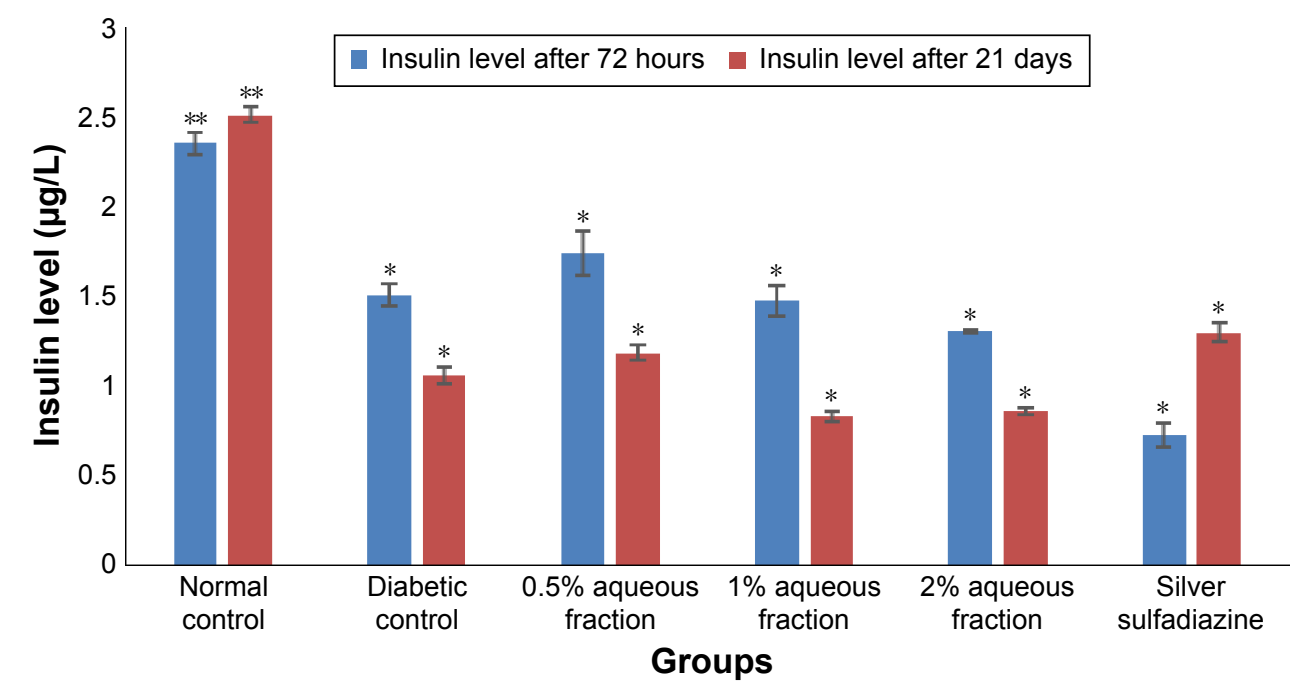

Figure 2 A graph comparing the concentration of insulin level of normal rats with streptozotocin-induced diabetic rats at 72 hours and 21 days after induction of diabetes. Notes: The high level of insulin in normal rats was more significant compared to diabetic rats. $* P<0.05$ normal control group versus diabetic groups. Values are mean \pm standard deviation of three independent readings.

were absent in untreated diabetic rats. Also, a well grown matured granulation tissue rich in new capillaries and newly deposited collagen fibers was seen in the treated groups compared to untreated diabetic control. This is shown in Figure 7.

The assessment of healing was also done using scoring of histological parameters from minimal-to-moderate appearance to indicate the degree of wound closure. Diabetic wounds treated with bioactive aqueous fraction showed better histologic scores compared to diabetic untreated wounds. This is shown in Table 4.

\section{Analysis of inflammatory mediators by ELISA}

The results of ELISA analysis showed that the levels of IL-1 $\beta$, IL-6, and TNF- $\alpha$ were downregulated 21 days after
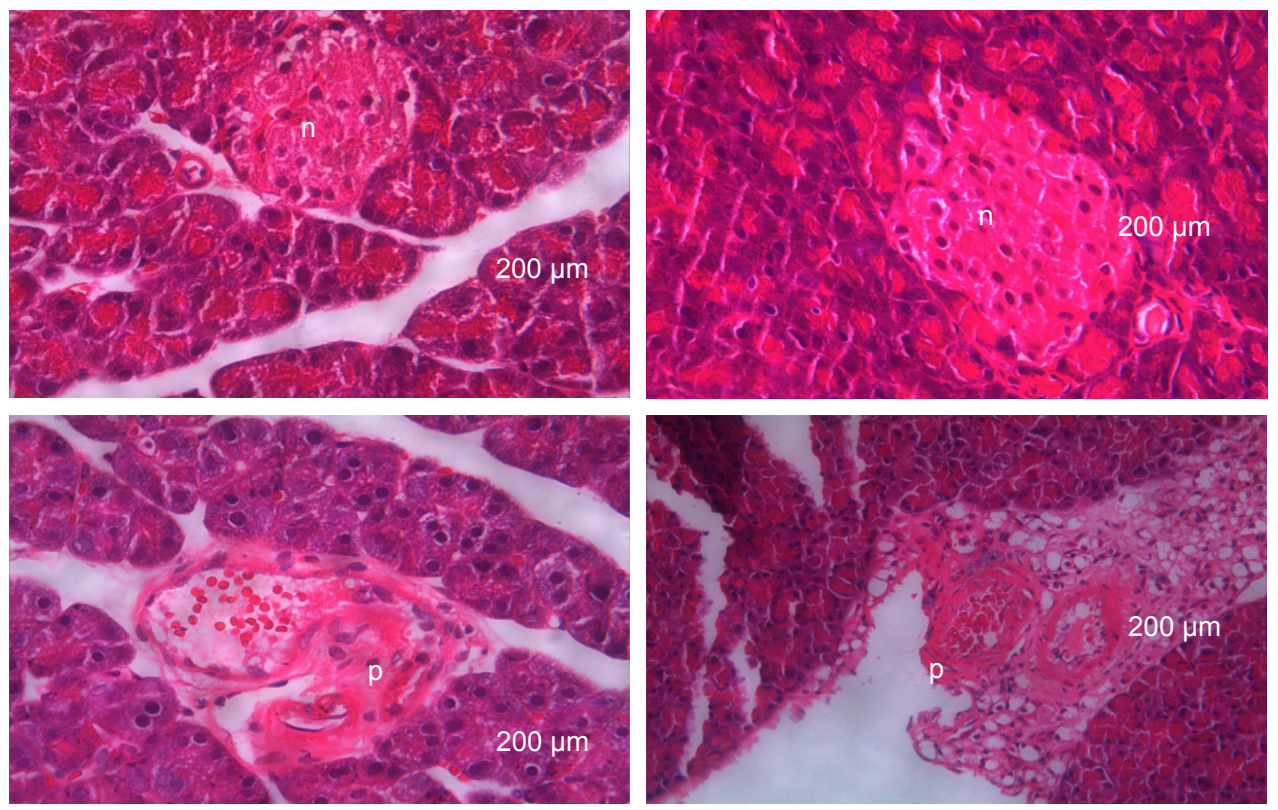

Figure 3 Histological features of hematoxylin-eosin stained sections of pancreatic tissue 21 days after induction of diabetes using a combination of streptozotocin and nicotinamide.

Notes: $n=A$ high intensity normal colored structure indicating presence of normal arrangement of islet of Langerhans in normal control rats. $\mathrm{p}=\mathrm{A}$ low intensity and partially destroyed colored structure indicating a partially destroyed islet of Langerhans ( $\times 20$ magnification). 


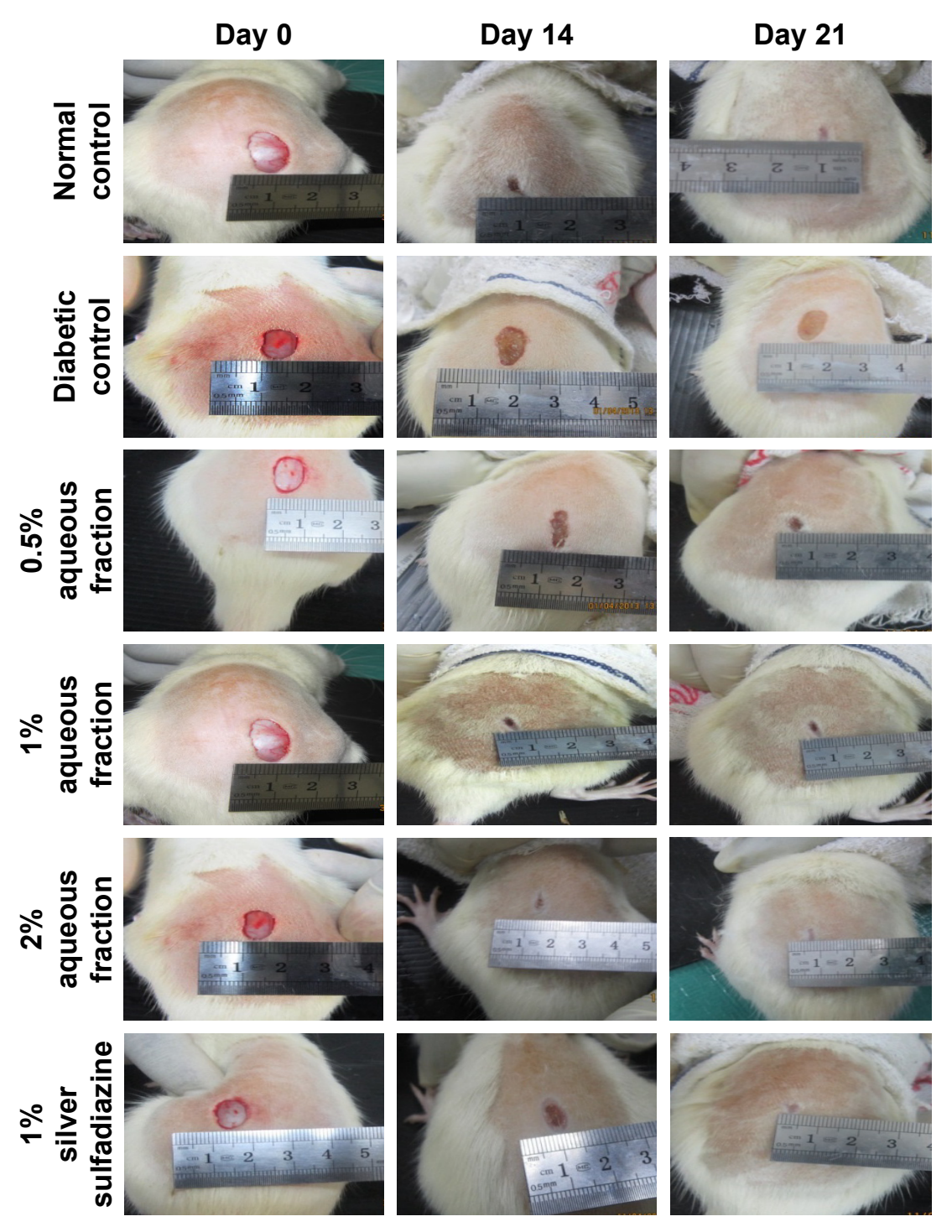

Figure 4 Digital photographs of excision wounds induced on normal control animals without treatment on day $0,3,7,14$, and 21 postwounding. Notes: The progress of healing indicated by the arrows showed healing was achieved by day 14 postwounding and progressed to complete wound closure after 21 days in the aqueous fraction treated groups compared to diabetic control that remained unhealed after $2 \mathrm{I}$ days treatment period.

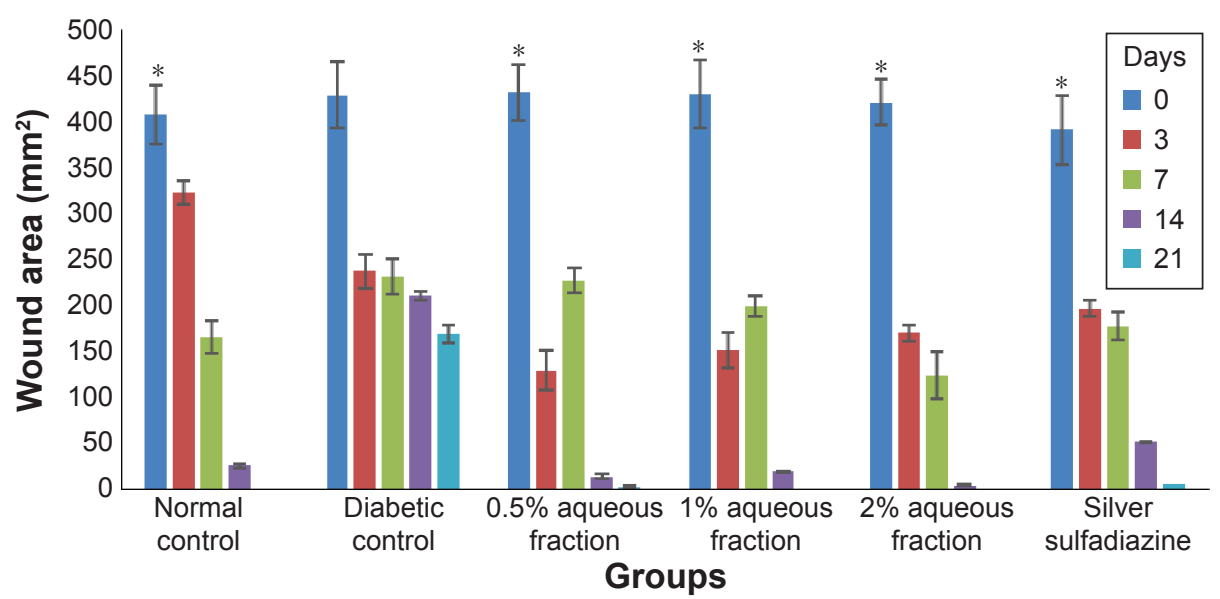

Figure $5 \mathrm{~A}$ graph of wound area analysis showing decrease in wound in diabetic-treated rats in a dose-dependent manner and the decrease was significant compared to untreated diabetic control $(* P<0.05)$.

Note: Data are mean \pm standard deviation of triplicate values. *Indicates greater significance. 


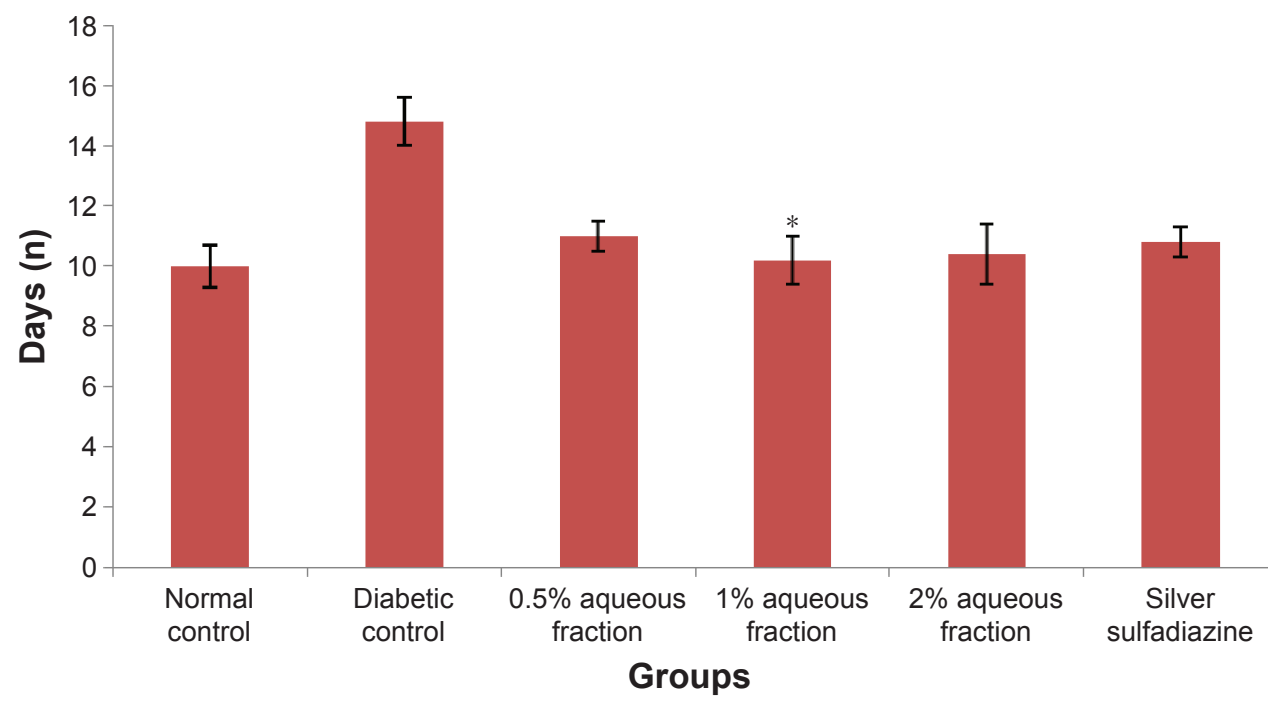

Figure 6 A graph of epithelialization period in control and diabetic-treated rats.

Notes: The decrease in epithelialization period in diabetic treated groups was significant compared to untreated diabetic control animals. $* P<0.05$. Data are mean \pm standard deviation of triplicate values.

treatment with various doses of aqueous fractions $(0.5 \%, 1 \%$, and $2 \%)$. The downregulation of these cytokines in diabetictreated rats was highly significant compared to nontreated diabetic control rats $(P<0.05)$. However, there was no significant difference in the downregulation of these cytokines between doses of aqueous fraction used (Figure 8).

\section{Analysis of cytokines by Western blotting}

The Western blotting results showed a proportionate upregulation of VEGF protein at wound site of diabetic animals treated with various doses $(0.5 \%, 1 \%$, and $2 \%)$ of aqueous fraction compared to untreated diabetic control group. Downregulations of COX-2 and iNOS were observed in diabetic
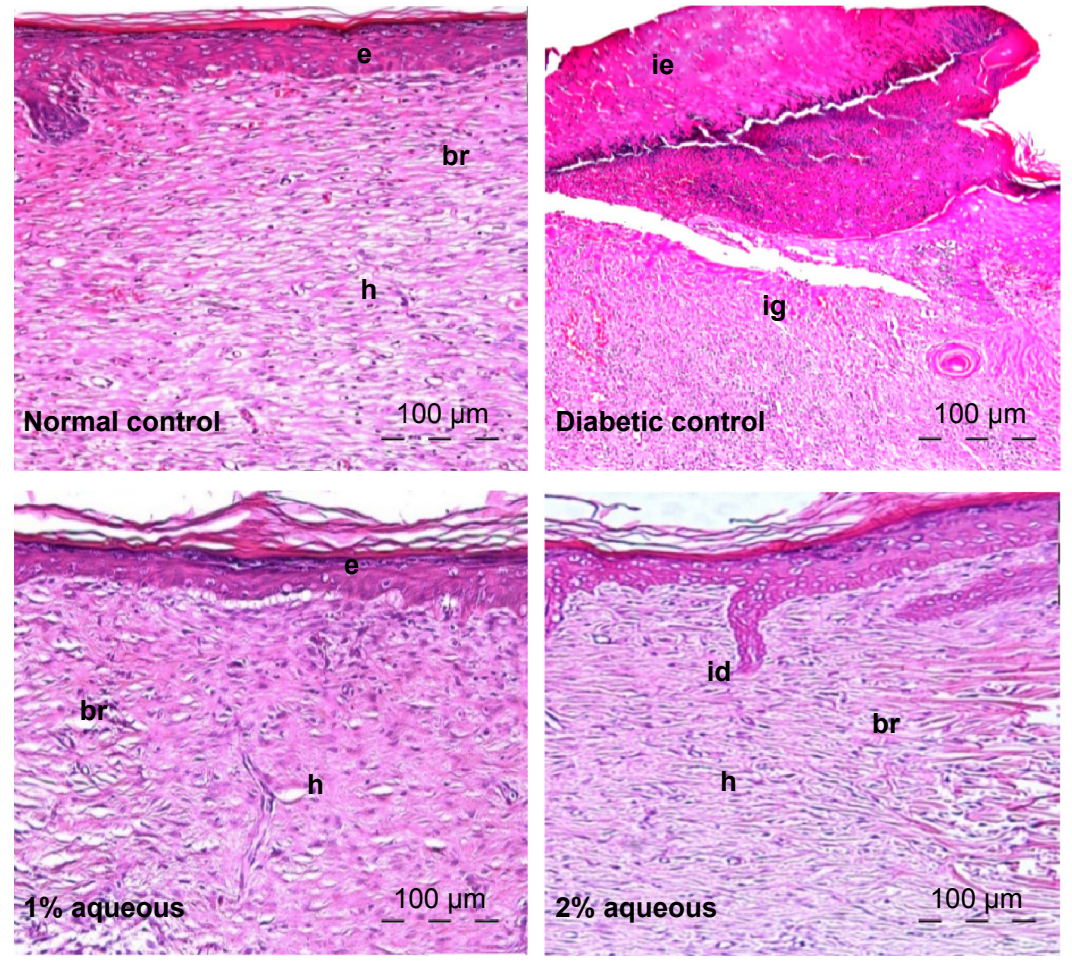
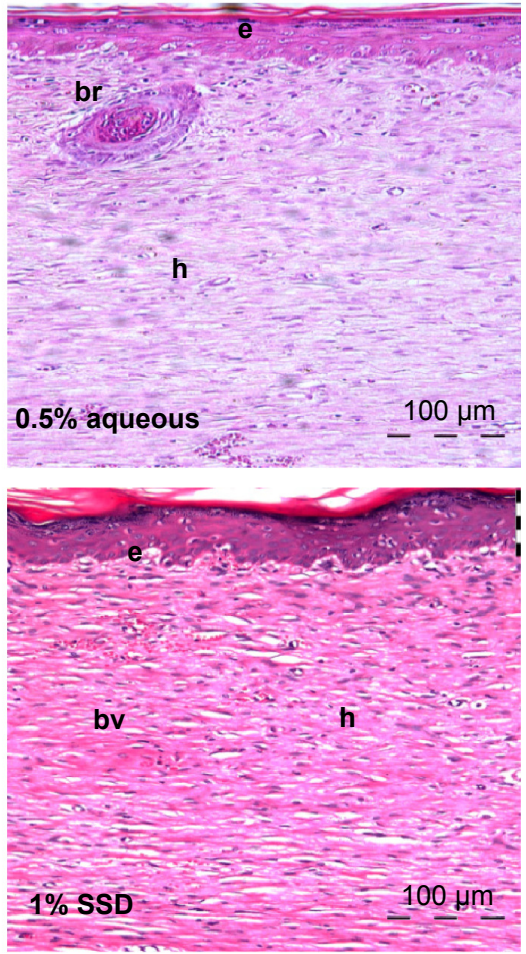

Figure 7 Hematoxylin-eosin histological sections of excisional wound site obtained from a diabetic wound treated with silver sulfadiazine (SSD).

Notes: Wistar rats on day $2 \mathrm{l}$ after wounding. (h): healed area with multiple layers of fibrous connective tissue; (br): boundary between unhealed and healed tissue; (ie): immature epidermis; (ig): immature granulation tissue; (bv): blood vessels; (id): interdigitation; (e): epithelium. Magnifications ( $\times 10)$. 
Table 4 Semiquantitative evaluation of histological parameters for the assessment of wound healing

\begin{tabular}{lllllllll}
\hline S no & Histological parameter & \multicolumn{7}{l}{ Groups } \\
\cline { 3 - 8 } & & i & ii & iii & iv & v & vi \\
\hline I & Epidermal regeneration & +++ & - & ++ & ++ & +++ & +++ \\
2 & Granulation tissue & ++ & - & ++ & ++ & ++ & +++ \\
3 & Inflammatory cells infiltration & - & ++ & + & + & + & - \\
4 & Angiogenesis & ++ & - & + & ++ & + & +++ \\
5 & Proliferation of fibroblast cells & ++ & - & ++ & ++ & ++ & ++ \\
6 & Collagen deposit & & ++ & - & ++ & ++ & ++ & ++ \\
\hline
\end{tabular}

Notes: +, slight; ++, moderate; +++, extensive; -, absence.

Abbreviation: S no, serial number.

treated groups compared to untreated diabetic control group. $\beta$-Actin was used as an internal loading control as shown in Figure 9. The results were further analyzed based on the intensity of the bands using image Lab software (Bio-Rad Laboratories Inc.) as shown in Figure 10.

\section{Determination of expression of VEGF antibody by immunohistochemistry}

Following 21 days of topical treatment with an aqueous fraction of $M$. oleifera, the intensity of VEGF expression (relative brown stain color) in the tissue was assessed and compared to untreated diabetic control rats. There was great intensity of VEGF expression in the granulation tissue and vascular endothelial cells in the wound of diabetic rats treated with various doses $(0.5 \%, 1 \%$, and $2 \%)$ aqueous fraction of M. oleifera. In the untreated diabetic rats, ulcerated epithelium and the granulation tissue showed absence of brown stain pigmentation indicating no expression of VEGF (Figure 11).

\section{Discussion}

The present study evaluated the antibacterial and in vivo efficacy of aqueous fraction of $M$. oleifera in promoting wound healing in an animal model of diabetes. The antibacterial properties exhibited by aqueous fraction of $M$. oleifera may be linked to the presence of some phytochemical compounds, such as alkaloids, triterpenoids, tannins, and flavonoids, in the extracts reported in our earlier study. ${ }^{42}$ These compounds are known to promote the wound healing process mainly due to their astringent and antimicrobial properties, which are responsible for wound contraction and increased rate of epithelialization. ${ }^{39,40,43}$ Microorganisms, especially bacteria, are known to play an important role in determining the degree of inflammatory response in wound healing. Wound healing is influenced by microorganisms, especially bacteria; ${ }^{43}$ some of these organisms, such as $S$. aureus and $P$. aeruginosa, have been reported to be among the common bacteria isolated in both acute and chronic wounds of various etiologies. ${ }^{44}$ Therefore, the aqueous fraction of $M$. oleifera strongly inhibiting the growth of these organisms suggests its ability to facilitate wound healing through antibacterial action. The MIC values of 3.125 and $6.25 \mu \mathrm{g} / \mathrm{mL}$ for aqueous fraction against $S$. aureus, $P$. aeruginosa, and $E$. coli indicated an effective concentration for antibacterial action. This is in accordance with a study that suggested isolated phytochemicals should have an MIC value $<1,000 \mu \mathrm{g} / \mathrm{mL}$ for them to be considered as potential therapeutic agents. ${ }^{45}$

In the present study, a combination of STZ $(65 \mathrm{mg} / \mathrm{kg})$ and NAD (150 mg/kg) was observed to cause some form of

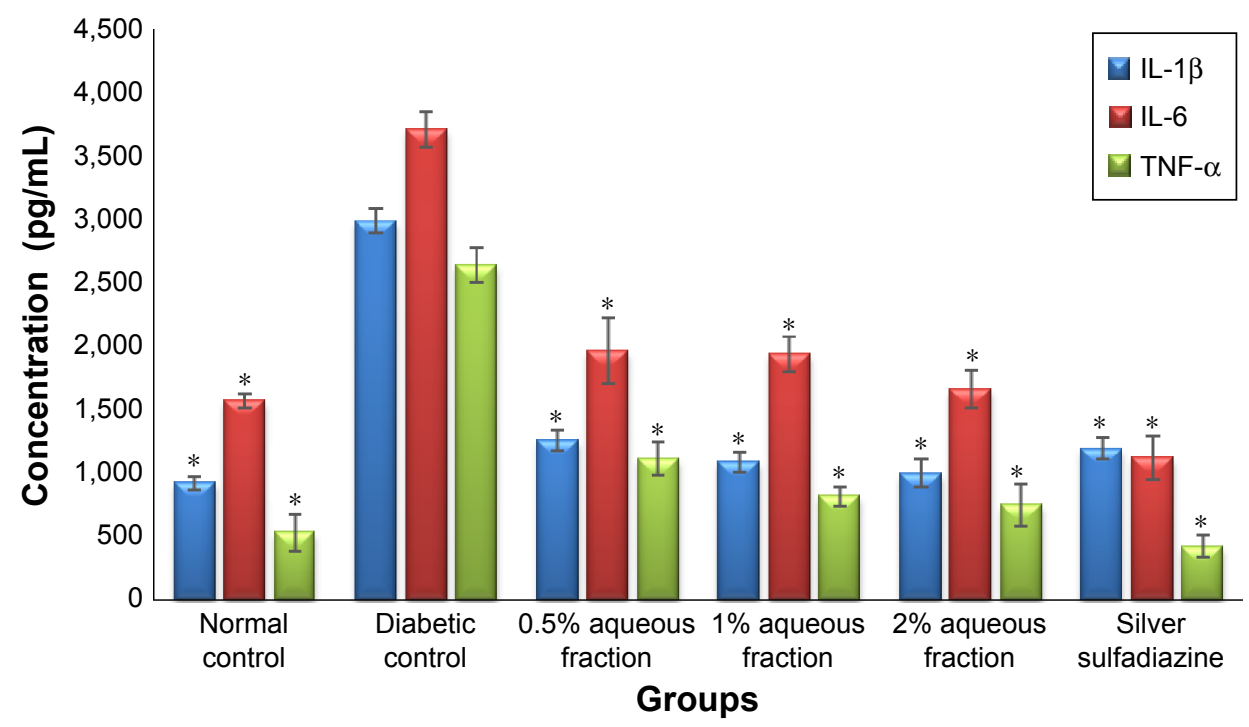

Figure $8 \mathrm{~A}$ graph of cytokine regulation showing downregulation of interleukin-I $\beta$ (IL-I $\beta$ ), interleukin-6 (IL-6), and tumor necrosis factor $\alpha$ (TNF- $\alpha$ ) in wound tissue treated 21 days after treatment.

Notes: The downregulation of cytokines level was highly significant in diabetic-treated rats compared to untreated diabetic control rats $(P<0.05)$. Data are mean \pm standard deviation of triplicate readings. *Indicates greater significance. 


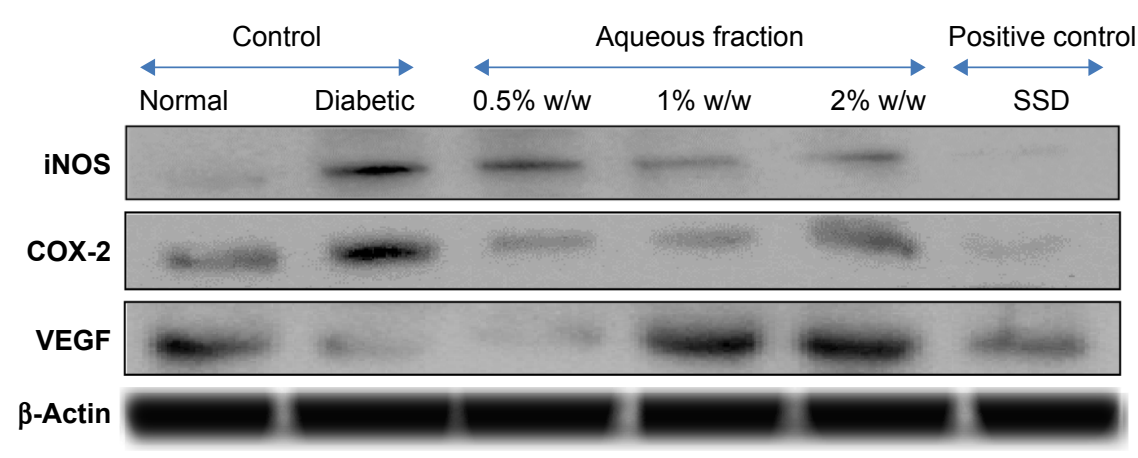

Figure 9 Effect of aqueous fraction on expression of cytokines showing upregulation and downregulation of various cytokines in tissues $2 \mathrm{I}$ days after treatment detected by Western blotting.

Abbreviations: SSD, silver sulfadiazine; VEGF, vascular endothelial growth factor; iNOS, inducible nitric oxide synthase.

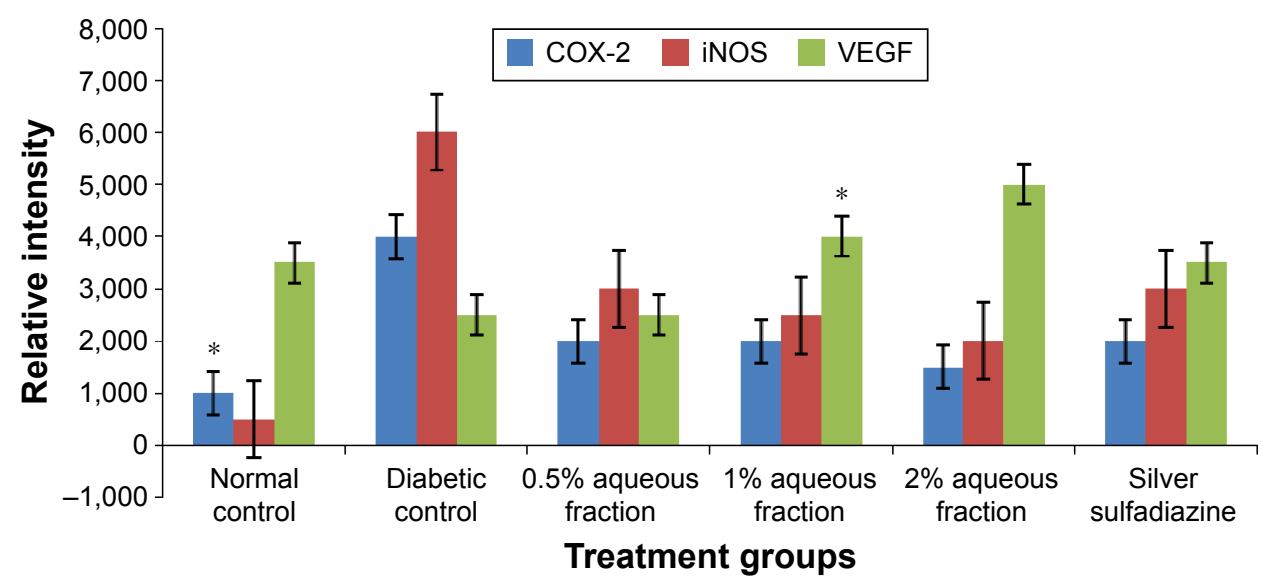

Figure $10 \mathrm{~A}$ graph showing analysis of expression of cytokines based on intensity of their bands obtained by image Lab software (Bio-Rad Laboratories Inc.). Notes: $* P<0.05$ versus untreated diabetic control. Data are mean \pm standard deviation of triplicate readings.

Abbreviations: VEGF, vascular endothelial growth factor; iNOS, inducible nitric oxide synthase.
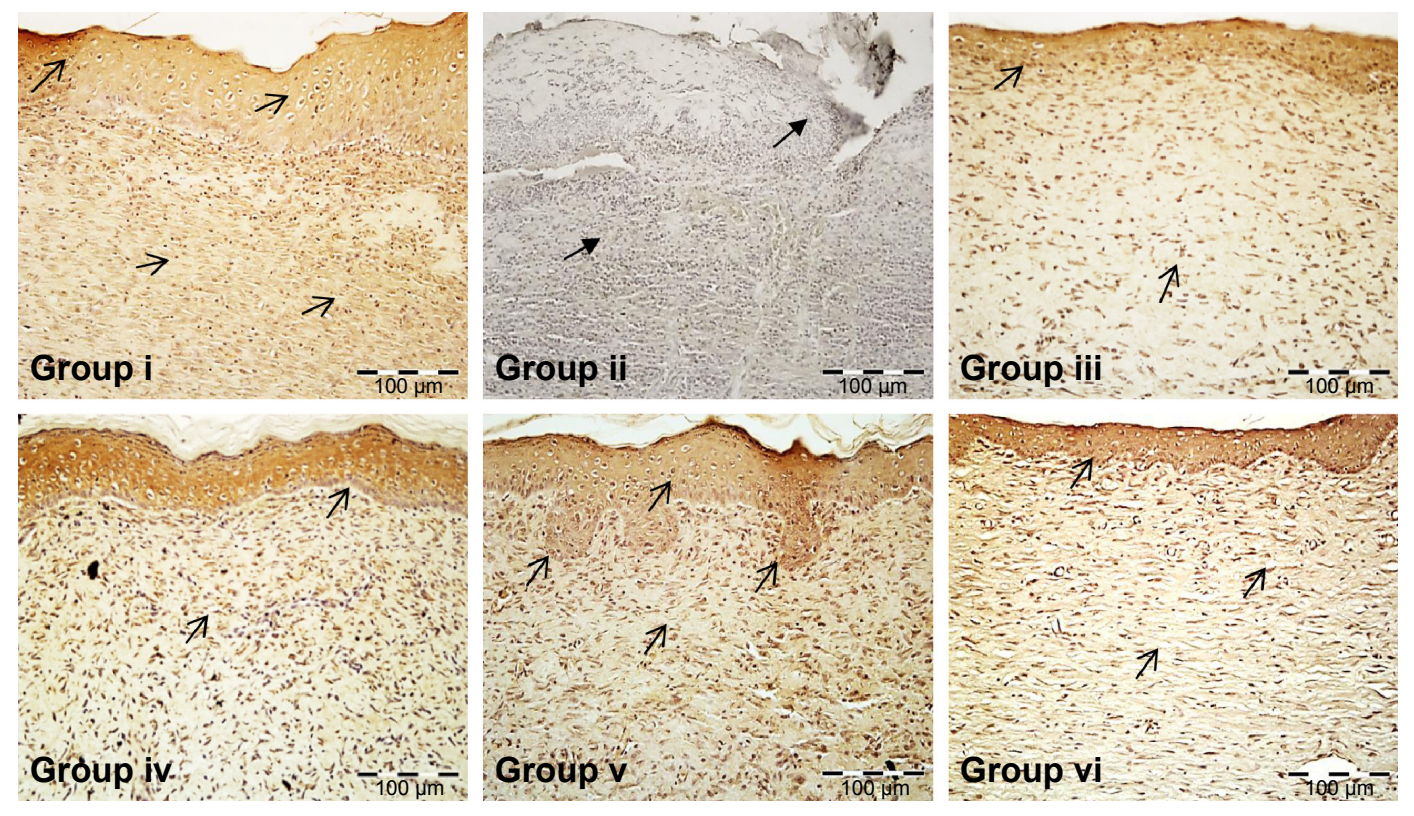

Figure I I Effect of aqueous fraction of Moringa oleifera on vascular endothelial growth factor expression showing relative brown stain indicated by the black arrows in wound tissue of treated diabetic rats in skin wound tissues 21 days postwounding.

Notes: (i): Normal control. (ii): Untreated diabetic control. (iii, iv, and v): $0.5 \%$, $1 \%$, and $2 \%$ aqueous fraction treated groups, respectively. (vi): Positive control treated with standard silver sulfadiazine (magnification $\times 20$ ). 
partial destruction of pancreatic $\beta$-cells, and some normal $\beta$-cells were seen to be preserved even after the administration of a low dose of STZ and NAD, which mimics the type 2 diabetes seen in humans. Elevated blood glucose levels were observed after 72 hours in all the rats induced with diabetes during the entire experimental period of 21 days. This finding is in accordance with other reported studies. ${ }^{34-36}$ The choice of topical application of aqueous fraction was because of advantages, such as availability of high and sustained concentration of these agents, at the site of injury with limited potential for systemic absorption and toxicity ${ }^{46}$ Similarly, it has been reported in a study that topically administered drugs are known to be effective in faster wound contraction, wound closure, and overall healing due to the desired local effect directly at the wound site. ${ }^{47}$ Wound healing process is known to be completed as soon as the damaged tissue is restored as closely as possible to its original state. Wound contraction, which is part of wound healing process that closes wounds to the external environment, ${ }^{48}$ is reported to be responsible for the shrinkage of the wounded area and healing primarily depends on the repairing ability of tissues in addition to type and degree of damage and general health status of the tissue. ${ }^{38}$ In the present study, topical application of bioactive aqueous fraction of M. oleifera showed an overall reduction of wound size and improved contraction rate in diabetic treated groups compared to untreated diabetic group (Figure S1). The highest dose of $2 \% \mathrm{w} / \mathrm{w}$ aqueous fraction showed a high contraction rate and reduced wound size as shown in Figures 5 and 6 , respectively. Therefore, these results support the effectiveness of aqueous fractions of $M$. oleifera in enhancing wound healing in diabetes. Similar observations have been reported in other studies in which wound size was significantly reduced and contraction rate significantly improved in diabetic experimental animals treated with a topical preparation of ball moss and lignum vitae $\mathrm{e}^{49}$ and Michelia champaca ${ }^{50}$ when compared to normal and diabetic controls.

The shorter periods of epithelialization and increased formation of granulation tissue observed in aqueous fraction treated groups when compared to untreated diabetic control groups could be among the factors that facilitated wound healing in animals. This observation is in accordance with a study by Murthy et a ${ }^{51}$ that reported faster wound healing in excision wound as a result of increased percentage of granulation tissue in Bacopa monniera extract treated animals compared to untreated control animals. Increased collagen deposition, regeneration, and well-aligned tissue (Figure S2) observed in aqueous fraction treated groups are in accordance with a study, which reported that prohealing parameters in wound healing could be due to increased collagen deposition and better alignment and maturation of wound tissue..$^{52}$

It has been established that tissue repair and wound healing are complex processes that involve inflammation, epithelialization, angiogenesis, granulation tissue formation, and deposition of interstitial matrix, beside other events carried out by different types of cells, such as keratinocytes, fibroblasts, inflammatory cells, and endothelial cells. ${ }^{53}$ In this study, complete regeneration of epidermis was generally found in diabetic groups treated with various doses of aqueous fraction of M. oleifera compared to untreated diabetic control group as shown in Figure 9. The regeneration of epidermis, matured granulation tissue, and less infiltration of inflammatory cells observed in aqueous fraction treated groups were similarly observed in normal and standard control groups. The untreated diabetic control group exhibited cellular infiltrations and immature granulation tissue. Our result is in accordance with a study which reported that diabetic wound impairs cellular infiltrations and consequently there is an inadequate granulation tissue formation..$^{54}$ The prohealing parameters observed in the aqueous fraction suggest that it has a restorative action on wound healing in diabetic rats. The delayed healing in untreated diabetic groups may be associated with an increased number of inflammatory cells and formation of immature granulation tissue. ${ }^{41,55}$

Another important aspect of wound healing is inflammation, which is regulated by several proinflammatory cytokines, such as IL-1 $\beta$, IL- 6 , and TNF- $\alpha$. These cytokines are potent inducers of MMP synthesis in fibroblasts and inflammatory cells. ${ }^{56}$ The persistent increase in concentrations of proteases during wound healing process gives rise to the pathogenesis of impaired wound healing. The high concentrations of proinflammatory cytokines and proteases stimulate wound cells to secrete proteases that destroy tissue and prevent the wound from closing. ${ }^{10}$ The inflammatory mediators released at wound site are thought to play a major role in wound repair via control of cell growth, migration, differentiation, and proliferation. ${ }^{57}$ The significant downregulation of proinflammatory cytokines (IL-1 $1 \beta$, IL-6, and TNF- $\alpha$ ) shown in Figure 10 in the aqueous fraction treated groups suggests a reduction in inflammatory state and consequent acceleration of wound healing. The significant changes in cytokines level are in accordance with other studies that linked decrease in proinflammatory cytokines level during healing of chronic wounds and the reduction in inflammatory state of wound. ${ }^{58}$ The downregulation of iNOS and COX 2 observed from diabetic wounds treated with various doses $(0.5 \%, 1 \%$, and $2 \%)$ of aqueous fraction 


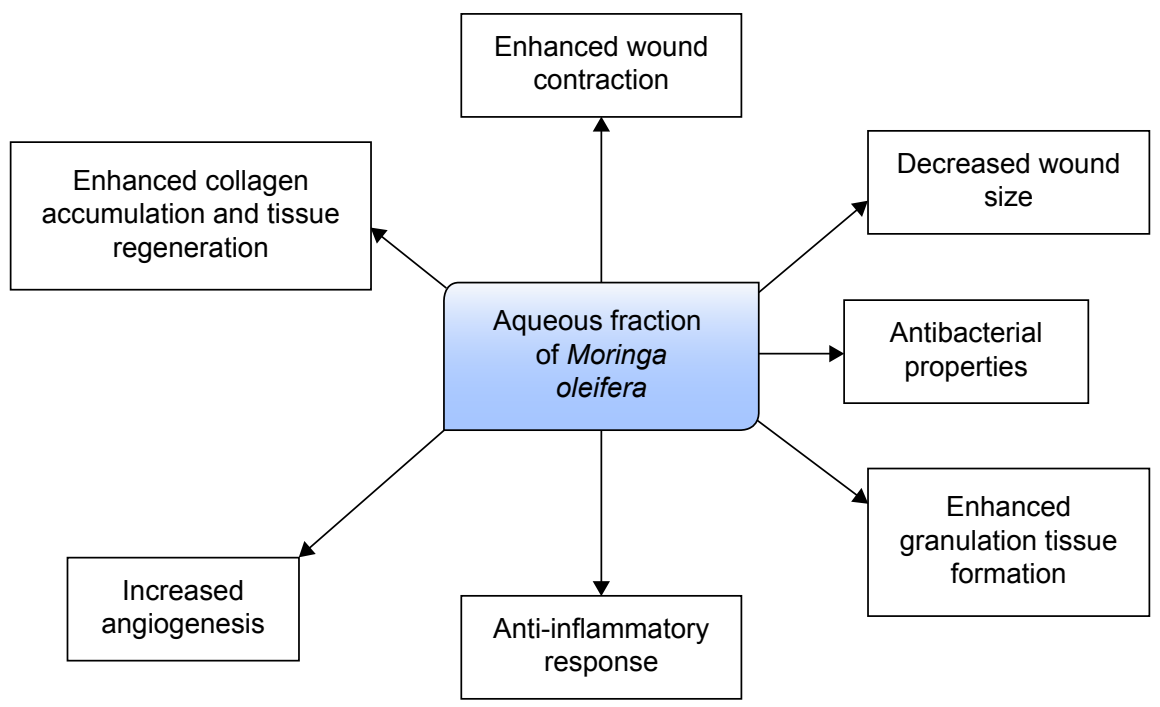

Figure 12 Possible mechanisms by which aqueous fraction enhances wound healing in diabetic condition.

compared to untreated diabetic control is important in the regulation of prolonged inflammatory response. This is in accordance with a study which reported that regulation of several enzyme systems and growth factors, such as COX 2 and iNOS, is vital for wound healing. ${ }^{59}$ VEGF has been implicated as one of the major proteinases and a prime candidate that promotes angiogenesis through activation and growth of endothelial cells, macrophages, and blood vessels. The promotion of angiogenesis by VEGF has been shown to significantly contribute to enhancement of wound healing in diabetes. ${ }^{60,61}$ The findings in this study revealed an expression of VEGF by different doses $(0.5 \%, 1 \%$, and $2 \%$ ) of aqueous fraction for 21 days is in agreement with a previous study that reported VEGF expression in late stage of wound healing. ${ }^{62}$ The finding also corroborates well with our earlier results of histopathology that revealed a complete regeneration of epidermis, high collagen deposition, angiogenesis, and epithelialization in the diabetic treated groups compared to untreated diabetic control group.

Therefore, findings from this investigation suggest that topical application of aqueous fraction of M. oleifera could have the possibility of accelerating angiogenesis through an angiogenic marker VEGF expression in diabetic rats and this result could enhance impaired wound healing in diabetic condition.

\section{Conclusion}

The present study has demonstrated the promising wound healing activity of an aqueous fraction of $M$. oleifera leaves in an animal model of hyperglycemia through improved wound contraction, epithelialization, and modulation of inflammatory mediators (Figure 12). This confirms the in vitro wound healing activity earlier reported by our group.

\section{Acknowledgment}

This study was supported by a university research grant scheme (RUGS) of Universiti Putra Malaysia (UPM Grant Nos: 9300379 and 9366700).

\section{Disclosure}

The authors report no conflicts of interest in this work.

\section{References}

1. International Diabetes Federation. IDF Diabetes Atlas. 6th ed. Brussels: International Diabetes Federation; 2014.

2. Sriyani KA, Wasalathanthri S, Hettiarachchi P, Prathapan S. Predictors of diabetic foot and leg ulcers in a developing country with a rapid increase in the prevalence of diabetes mellitus. PloS one. 2013;8(11): e80856.

3. Singh N, Armstrong DG, Lipsky BA. Preventing foot ulcers in patients with diabetes. JAMA. 2005;293(2):217-228.

4. Zaine NH, Burns J, Vicaretti M, Fletcher JP, Begg L, Hitos K. Characteristics of diabetic foot ulcers in Western Sydney, Australia. $J$ Foot Ankle Res. 2014;7(1):39.

5. Wu S, Armstrong DG. Risk assessment of the diabetic foot and wound. Int Wound J. 2005;2:17-24.

6. Boulton AJM, Cavanagh PR, Rayman G, editors. The Foot in Diabetes. 4th ed. Chichester, UK: Wiley and Sons Ltd; 2006.

7. Abbas ZG. The global burden of diabetic foot. In: Pendsey S, editor. Contemporary Management of the Diabetic Foot. 1st ed. New Delhi: Jaypee Brothers Medical Publishers (P) Ltd.; 2013.

8. Boulton A. The diabetic foot: Epidemiology, risk factors, and the status of care. Diabetes VOICE. 2005;50(SI):5-7.

9. Yusof MI, Sulaiman AR, Muslim DA. Diabetic foot complications: a two-year review of limb amputation in a Kelantanese population. Singapore Med J. 2007;48(8):729-732.

10. Guo S, DiPietroJ LA. Factors affecting wound healing. J Dental Res. 2010;89(3):219-229.

11. Song JJ, Salcido R. Use of honey in wound care: An update. Adv Skin Wound Care. 2011;24(1):40. 
12. Frankel YM, Melendez JH, Wang NY, Price LB, Zenilman JM, Lazarus GS. Defining wound microbial flora. Molecular microbiology opening new horizons. Arch Dermatol. 2009;145(10):1193-1195.

13. Houghton PJ, Hylands PJ, Mensah AY, Hensel A, Deters AM. In vitro tests and ethnopharmacological investigations: wound healing as an example. J Ethnopharmacol. 2005;100(1-2):100-107.

14. Howell-Jones RS, Wilson MJ, Hill KE, Howard AJ, Price PE, Thomas DW. A review of the microbiology, antibiotic usage and resistance in chronic skin wounds. J Antimicrob Chemother. 2005;55(2):143-149.

15. Sweitzer SM, Fann SA, Borg TK, Baynes JW, Yost MJ. What is the future of diabetic wound care? Diabetes Educ. 2006;32(2):197-210.

16. Ponrasu T, Suguna L. Efficacy of Annona squamosa on wound healing in streptozotocin-induced diabetic rats. Int Wound J. 2012;9(6): 613-623.

17. Fahey JW. Moringa oleifera: A review of the medical evidence for its nutritional, therapeutic, and prophylactic properties. Part 1. Phytochemistr. 2005; 47:123,157.

18. Biswas TK, Maity LN, Mukherjee B. Wound healing potential of Pterocarpus santalinus Linn: a pharmacological evaluation. Int J Low Extrem Wounds. 2004;3(3):143-150.

19. Anwar F, Latif S, Ashraf M, Gilani AH. Moringa oleifera: a food plant with multiple medicinal uses. Phytother Res. 2007;21(1):17-25.

20. Prashith Kekuda TR, Mallikarjun N, Swathi D, Nayana KV, Meera B, Aiyar TR. Antibacterial and antifungal efficacy of steam distillate of Moringa oleifera Lam. J Pharm Sci Res. 2010;2(1):34-37.

21. Mahajan SG, Mali RG, Mehta AA. Protective effect of ethanolic extracts of seeds of Moringa oleifera lam. against inflammation associated with development of arthritis in rats. J Immunotoxicol. 2007;4(1): 39-47.

22. Nandave M, Ojha SK, Joshi S, Kumari S, Arya DS. Moringa oleifera leaf extract prevents isoproterenol-induced myocardial damage in rats: Evidence for an antioxidant, antiperoxidative, and cardioprotective intervention. J Med Food. 2009;12(1):47-55.

23. Al-Asmari AK, Albalawi SM, Athar MT, Khan AO, Al-Shahrani H, Islam M. Moringa oleifera as an anti-cancer agent against breast and colorectal cancer cell lines. PLoS One. 2015;10(8):e0135814.

24. Fakurazi S, Nanthini U, Hairuszah I. Hepatoprotective and antioxidant action of Moringa oleifera lam. against acetaminophen induced hepatotoxicity in rats. Int J Pharmacol. 2008;4(4):270-275.

25. Sharifudin SA, Fakurazi S, Hidayat MT, Hairuszah I, Aris Mohd Moklas M, Arulselvan P. Therapeutic potential of Moringa oleifera extracts against acetaminophen-induced hepatotoxicity in rats. Pharm Biol. 2013;51(3):279-288.

26. Fakurazi S, Sharifudin SA, Arulselvan P. Moringa oleifera hydroethanolic extracts effectively alleviates acetaminophen-induced hepatotoxicity in experimental rats through their antioxidant nature. Molecules. 2012;17(7):8334-8350.

27. Hamza AA. Ameliorative effects of Moringa oleifera lam seed extract on liver fibrosis in rats. Food Chem Toxicol. 2010;48(1): $345-355$.

28. Muhammad AA, Pauzi NA, Arulselvan P, Abas F, Fakurazi S. In vitro wound healing potential of Moringa oleifera and identification of bioactive compounds. Biomed Res Int. 2013;2013:974580.

29. Hashim NH, Abas F, Shaari K, Lajis NH. LC-DAD-ESIMS/MS characterization of antioxidant and anticholinesterase constituents present in the active fraction from Persicaria hydropiper. LWT - Food Sci Technol. 2012;46(2):468-476.

30. Irobi ON, Moo-Young M, Daramola SO. Antimicrobial activity of Annatto (Bixa orellana) extract. Int J Pharmacognosy. 1996;34(2): 87-90.

31. Andrew JM. Determination of MIC. J Antimicrob Chemother. 2001; 48(Suppl 1):5-16.

32. Thakur R, Jain N, Pathak R, Sandhu SS. Practices in wound healing studies of plants. Evid Based Complement Alternat Med. 2011;2011:438056. doi: $10.1155 / 2011 / 438056$

33. Pattanayak S, Nayak S, Dinda SC, Panda D, Navale K. Evaluation of herbal ointments formulated with methanolic extract of cajanus scarabaeoides. Journal of Pharmacy and Allied Health Sciences. 2001; 1:49-57.
34. Pauzi NS, Muhammad AA, Fakurazi S, Arulselvan P, Ahmad Z. Preliminary study of the optimization of protocol for development of type 2 diabetic model in rats. Indian J Sci Tech. 2013;6(7): 4960-4965.

35. Masiello P, Broca C, Gross R, et al. Experimental NIDDM: development of a new model in adult rats administered streptozotocin and nicotinamide. Diabetes. 1998;47(2):224-229.

36. Pimple BP, Kadam PV, Patil MJ. Ulcer healing properties of different extracts of Origanum majorana in streptozotocin-nicotinamide induced diabetic rats. Asian Pac J Trop Dis. 2012;2(4):312-318.

37. Khorshid F, Ali SS, Alsofyani T, Albar H. Plectranthus tenuiflorus (shara) promotes wound healing: In vitro and in vivo studies. Int $J$ Bot. 2010;6(2):69-80

38. Teoh SL, Latiff AA, Das S. The effect of topical extract of Momordica charantia (bitter gourd) on wound healing in non-diabetic rats and in rats with diabetes induced by streptozotocin. Clin Exp Dermatol. 2009;34(7):815-822.

39. Nayak B, Pereira LP. Catharanthus roseus flower extract has woundhealing activity in Sprague Dawley rats. BMC Complement Altern Med. 2006;6(1):41.

40. Dash G, Murthy P. Studies on wound healing activity of Heliotropium indicum linn. Leaves on rats. ISRN Pharmacol. 2011;2011:847980.

41. Abu-Al-Basal MA. Healing potential of Rosmarinus officinalis L. on full-thickness excision cutaneous wounds in alloxan-induced-diabetic BALB/c mice. J Ethnopharmacol. 2010;131(2):443-450.

42. Muhammad AA, Arulselvan P, Karthivashan G, Fakurazi S. In vitro antioxidant properties of bioactive fraction of Moringa oleifera. $J$ Nat Prod Biomed Res. 2015;1(2):51-56.

43. Edwards R, Harding KG. Bacteria and wound healing. Curr Opin Infect Dis. 2004;17(2):91-96.

44. Pastar I, Nusbaum AG, Gil J, et al. Interactions of methicillin resistant Staphylococcus aureus USA300 and Pseudomonas aeruginosa in polymicrobial wound infection. PLoS One. 2013;8(2):e56846.

45. Gibbons S. Plants as a source of bacterial resistance modulators and antiinfective agents. Phytochem Rev. 2005;4:63-78.

46. Lipsky BA, Hoey C. Topical antimicrobial therapy for treating chronic wounds. Clin Infect Dis. 2009;49(10):1541-1549.

47. Panchatcharam M, Miriyala S, Gayathri VS, Suguna L. Curcumin improves wound healing by modulating collagen and decreasing reactive oxygen species. Mol Cell Biochem. 2006;290(1-2):87-96.

48. Hsu A, Mustoe TA. The principles of wound healing. Plastic Surgery Secrets Plus. 2010:3-7.

49. Bahado-Singh PS, Riley CK, Lowe HI, Watson CT, Wheatley AOB, Morrison ESAY. Wound healing potential of Tillandsia recurvata and Guaiacum officinale in streptozotocin induced type 1 diabetic rats. Am J Biomed Life Sci. 2014;2(6):146-149.

50. Gowda A, Shanbhag V, Shenoy S, Bangalore ER, Prabhu KMR. Wound healing property of topical application of ethanolic extract of Michelia champaca flowers in diabetic rats. Int J Pharmacol Clin Sci. 2013;2(3):67-74.

51. Murthy S, Gautam MK, Goel S, Purohit V, Sharma H, Goel RK. Evaluation of in vivo wound healing activity of Bacopa monniera on different wound model in rats. BioMed Research International. 2013; 972028.

52. Rathi B, Bodhankar S, Baheti A. Evaluation of aqueous leaves extract of Moringa oleifera Linn for wound healing in albino rats. Indian J Exp Biol. 2006;44(11):898.

53. Liu H, Lin S, Xiao D, Zheng X, Gu Y, Guo S. Evaluation of wound healing potential of resina draconis (Dracaena cochinchinensis) in animal models. Evidence-Based Complementary and Alternative Medicine. 2013;709865.

54. Gutiérrez-Fernández A, Inada M, Balbín M, et al. Increased inflammation delays wound healing in mice deficient in collagenase-2 (MMP-8). FASEB J. 2007;21(10):2580-2591.

55. Hirsch T, Spielmann M, Zuhaili B, et al. Human beta-defesinin-3 promotes wound healing in infected diabetic wounds. J Gene Med. 2008; 11(3):220-228 
56. Lobmann R, Ambrosch A, Schultz G, Waldmann K, Schiweck S, Lehnert H. Expression of matrix-metalloproteinases and inhibitors in wounds of diabetic and non-diabetic patients. Diabetologia. 2002; 45(7):1011-1016.

57. Bryan D, Walker KB, Ferguson M, Thorpe R. Cytokine gene expression in a murine wound healing model. Cytokine. 2005;31(6):429-438.

58. Trengove NJ, Bielefeldt-Ohmann H, Stacey MC. Mitogenic activity and cytokine levels in non-healing and healing chronic leg ulcers. Wound Repair Regen. 2000;8(1):13-25.

59. Kapoor M, Howard R, Hall I, Appleton L. Effects of Epicatechin gallate on wound healing and scar formation in a full thickness incisional wound healing model in rats. Am J Pathol. 2004;165(1):299-307.
60. Nogami M, Hoshi T, Kinoshita M, Arai T, Takama M, Takahashi I. Vascular endothelial growth factor expression in rat skin incision wound. Med Mol Morphol. 2007;40(2):82-87.

61. Hong YK, Lange-Asschenfeldt B, Velasco P, et al. VEGF-A promotes tissue repair-associated lymphatic vessel formation via VEGFR-2 and the $\alpha 1 \beta 1$ and $\alpha 2 \beta 1$ integrins. FASEB J. 2004;18(10):1111-1113.

62. Werner S, Grose R. Regulation of wound healing by growth factors and cytokines. Physiol Rev. 2003;83(3):835-870. 


\section{Supplementary materials}

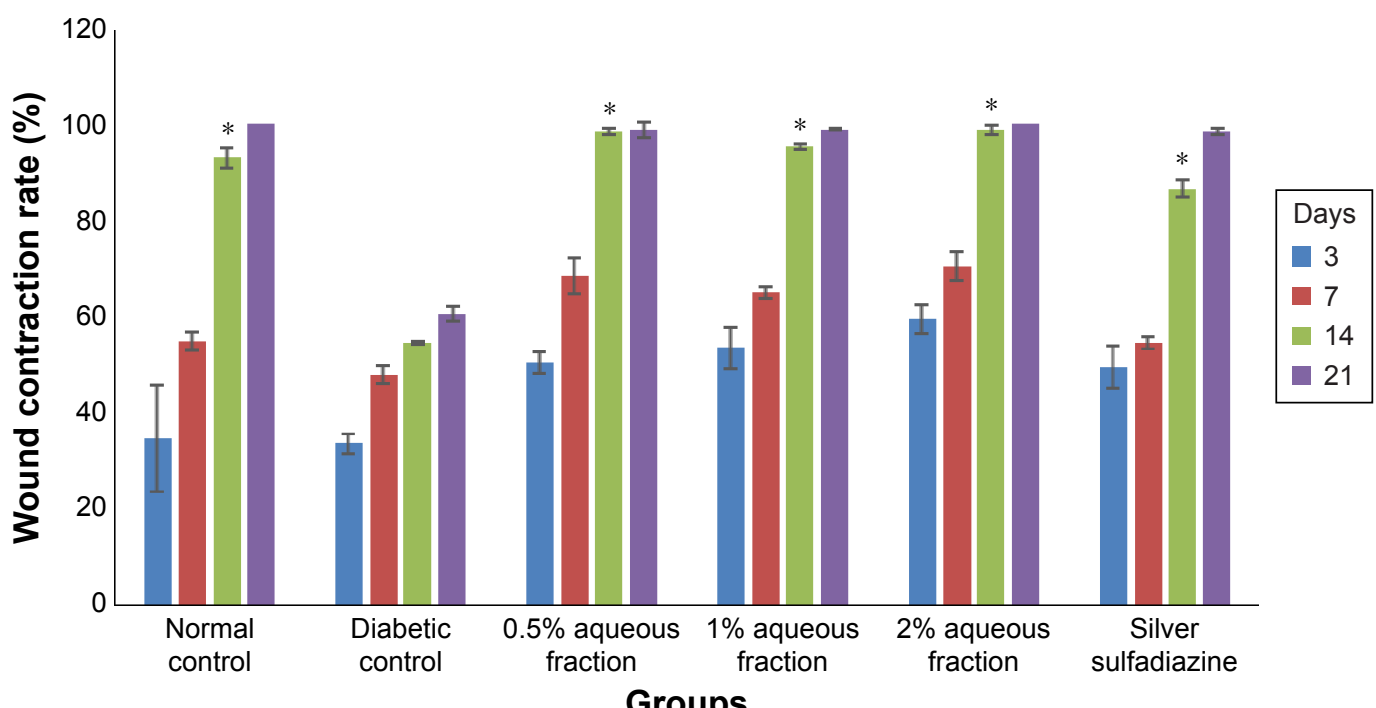

Figure SI A graph of wound contraction rate in control and diabetic treated animals.

Notes: This improved contraction rate in diabetic-treated rats was significant compared to the untreated diabetic control $(* P<0.05)$. Data are mean \pm standard deviation of triplicate values. *Indicates greatest significance.

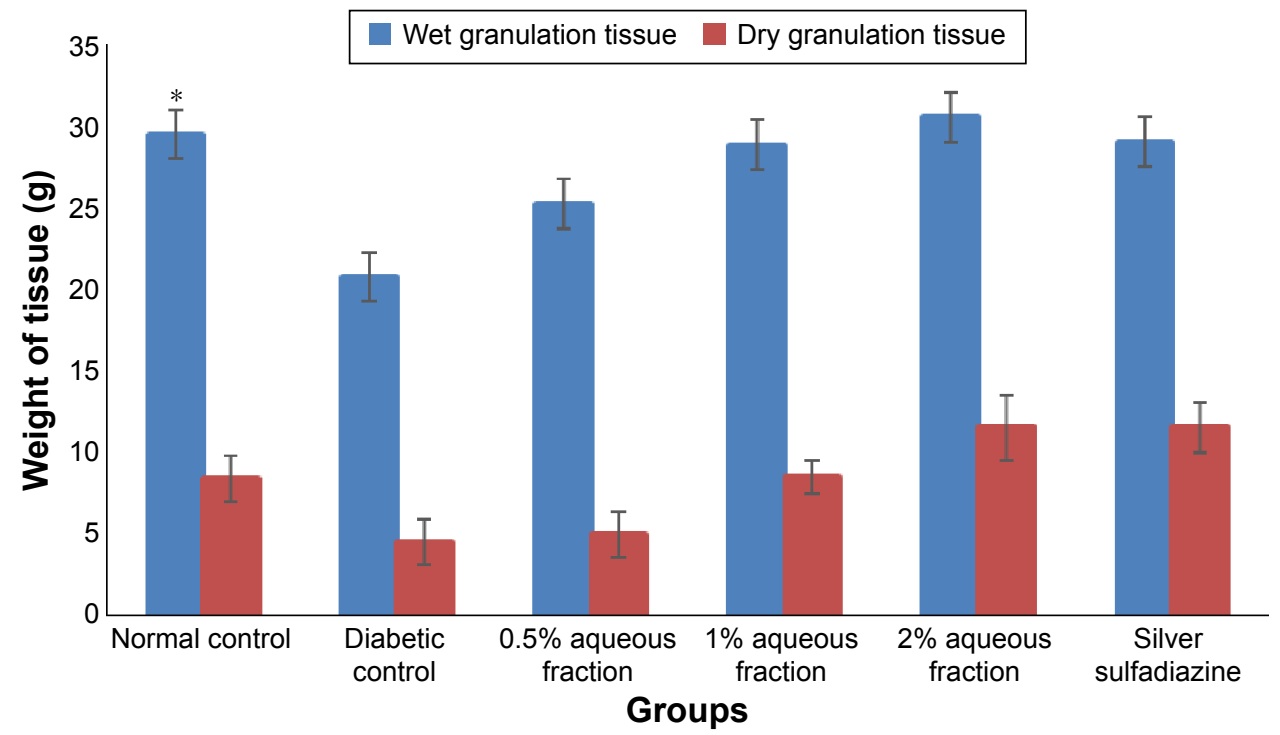

Figure S2 A graph showing estimates of amount of granulation tissue formed in control and diabetic rats.

Notes: The amount of granulation tissue formed in diabetic-treated rats was significantly higher compared to untreated diabetic control rats. $* P<0.05$. Data are mean \pm standard deviation of triplicate readings.

\section{Publish your work in this journal}

Drug Design, Development and Therapy is an international, peerreviewed open-access journal that spans the spectrum of drug design and development through to clinical applications. Clinical outcomes, patient safety, and programs for the development and effective, safe, and sustained use of medicines are a feature of the journal, which has also been accepted for indexing on PubMed Central. The manuscript management system is completely online and includes a very quick and fair peer-review system, which is all easy to use. Visit http://www.dovepress.com/testimonials.php to read real quotes from published authors 